\title{
The Political Economy of Early Chicano Historiography: The Case of Hubert H. Bancroft and Mariano G. Vallejo
}

Marissa López

In 1973, the eminent Chicano literary critic Juan Bruce-Novoa wrote, "Chicano literature is in danger of being shackled to superficial characteristics" (14). He was lamenting the tendency of critics and publishers to insist on easily identifiable traits such as language and the barrio experience in order to consider literature 'Chicano'. Although our arguments have become more nuanced, the essential conditions Bruce-Novoa decried have not changed much since 1973. Chicano literary criticism still tends toward an ideological parochialism, defining Chicano literature in terms of its expressions of oppression and opposition. Nowhere is this more clear than in discussions of nineteenth-century Californio writer Mariano Vallejo's 1875 memoir Recuerdos Historicos y Personales Tocante á la Alta California (Historical and Personal Recollections Touching upon Alta California). Troubled by Vallejo's position as a wealthy, pro-US Mexican ranchero, scholars have focused solely on his critique of the US and his articulations of what they view as proto-Chicano politics. Such treatment, however, glosses his enthusiastic endorsement of the free market and disregards his literary and philosophical contributions to nationalist debates in late nineteenth-century California. Reading Vallejo's memoir as an extended meditation on historical narrative and international law, rather than as an elegy for his disappearing community, highlights the complex interpretive processes that enable ethnic identity. Such an approach also offers a model for Chicano critical strategies that

Marissa López is an Assistant Professor of English at UCLA, where she is also affiliated with the Department of Chicana and Chicano Studies and the Chicana/o Studies Research Center. 
[Vallejo's and

Bancroft's] respective histories of California reveal complex processes of national identification at work, and suggest wealthy rancheros play a constitutive role in Chicana/o literary history. allow for Chicano literature to craft its own world of meaning, rather than responding to and fitting itself within the confines of Anglo-American oppression.

Vallejo, former Mexican military commander of Alta California, wrote his Recuerdos at the request of San Franciscobased, Anglo-American historian Hubert H. Bancroft. In his own memoir, Literary Industries (1915), Bancroft describes his relationship with Vallejo, and how he convinced Vallejo to contribute to his project of chronicling the history of the western US, Central America, and South America. In this article I consider Vallejo's Recuerdos in relation to Bancroft's Works, investigating the intersections of historical narrative with nationalist sentiment in the seven volumes dedicated to California. The two men's respective histories of California reveal complex processes of national identification at work, and suggest wealthy rancheros play a constitutive role in Chicana/o literary history.

Vallejo's narrative is part of the collection of oral narratives gathered by Bancroft's staff, regarded as comprising one of the foundational genres of Chicana/o literature. These testimonios, which document the lives of Mexican Californians in the wake of the Mexican-American War of 1846-48, have been examined extensively by scholars such as Rosaura Sánchez, in Telling Identities: The Californio Testimonios (1995), and Genaro Padilla, in My History Not Yours: The Formation of Mexican American Autobiography (1993). Vallejo's text figures prominently in both studies, and part of my project here is to challenge these scholars' portrayals of his narrative. Although Vallejo and his text share some of the characteristics of the testimonio and its presumed narrator, the generic differences in the Recuerdos are crucial to understanding the new order of class and race consciousness emerging in late nineteenth-century California. Vallejo's place in the Chicana/o literary tradition arises out of this nexus.

Sánchez's reading of Vallejo relies on her assertion that he narrates a collective identity forged out of loss. However, Vallejo's public assertion that he avoided mentioning personal details in the service of historical truth, which Sánchez cites (9), speaks less to a burgeoning collective identity and more to Vallejo's own history as a public servant frequently accused of self-aggrandizing and self-serving motives. ${ }^{1}$ I take issue with the notion that Vallejo imagined himself to be narrating a collectivity. Interpretations such as Sánchez's and Padilla's-who reads Vallejo's and Bancroft's printed disputes over historical documentation as analogous to the US's conquest of Mexico-emphasize notions of self, identity, and dispossession, all of which converge to form the grounding of a proletarianized and racialized Chicana/o community that emerges 
in the 1960s. These readings emphasize contemporary realities over past concerns and so limit the range of observations we can make about Vallejo, who, like many wealthy Californios, saw his fortunes devastated after the Mexican-American War of 1846-48 and the Land Act of $1851 .^{2}$ Close readings of his memoirs and personal papers reveal that he did not understand himself as marginalized in the way Sánchez's and Padilla's readings position him.

Vallejo is less concerned with articulating his self or a subaltern community, than he is with writing history and analyzing international policy. I argue that Bancroft's and Vallejo's narratives articulate competing modes of nationalism that emerge and gain political force concomitant with sweeping economic changes in the post-Civil War US. In teasing out the various trajectories of Mexican-American racialization in California through an analysis of Bancroft's and Vallejo's histories, we come to see how philosophies of history and economics manifest themselves in narratives of the nation, how these narratives are integral to the construction of ethnic identities, and how they give us more nuanced ways to understand interracial, interethnic, and international relations and texts.

As the US consolidated its post-Civil War national economy, the Californio economy continued to fracture, witnessing economic depression, increased industrialization and urbanization, and a move from small- to large-scale capitalist farming. These rapid shifts structured both men's sense of self, ${ }^{3}$ yet thinking only in terms of twentieth- or twenty-first-century notions of racial and ethnic conflict and identity does not do justice to Bancroft's or Vallejo's historical narratives. Instead, following theorists such as Michael Omi, Howard Winant, Tomás Almaguer, and Evelyn Nakano Glenn, I argue that historical narratives are central to the formation of racial and ethnic communities and that national ideologies are imbricated in modes of historical discourse. ${ }^{4}$ To more fully understand the present, we must not use the present to unpack the past's complexities. Rather, we must try to understand the past on its own terms in order to assess its constitutive role in the present.

Ethnicities and nationalisms change over time, and historically situated narratives allow us a synchronic view of their evolution. When I argue for Vallejo's place in Chicana/o literary history, then, I mean not to cast him in the highly politicized light of one who might identify as Chicana/o, but rather to suggest that his text inaugurates a textual mode of Chicana/o nationalism, defined as a set of economic relations to self and history articulated within the nexus of national institutions structuring class and 
racial identities, as I will elaborate in my close readings of the Recuerdos. Placing Vallejo in this context argues for his incorporation into the Chicana/o literary tradition, an incorporation that accomplishes two distinct aims. First, it emphasizes the temporal mutability of "Chicano" as a highly charged term, providing a way to think through the relevance of the nineteenth century to contemporary Chicana/o letters. Such connections have been difficult for scholars to parse, committed as they may be to contemporary Chicana/o and Latina/o political realities. As Kirsten Gruesz compellingly argues in Ambassadors of Culture: The Transamerican Origins of Latino Writing (2002), however, nineteenth-century Latino writers' class and race positions vitiate their significance for neither nineteenth-century nor contemporary American literature (xi). My use of "American" gestures toward the second aim achieved by placing Vallejo in the context of Chicano nationalism: the redefinition of the nation as a component of global culture.

My argument here parallels Gruesz's study of the personal and literary relationships of Latin American and US authors that demonstrate both the significant Latina/o literary presence in the US during the nineteenth century and establish a "commonality of Latino expression" (xi) that transcends national division. Living as he did in the cultural backwater that many viewed California to be, Vallejo was nevertheless a part of the Latino expression Gruesz traces. ${ }^{5}$ Deeply committed to his own community, Vallejo also recognizes the need to develop a global perspective and to establish connections to empower Californios. Vallejo's expansiveness makes him a key figure for Chicana/o literary nationalism as I am defining it here. Gruesz suggests that the challenge of changing US demographics is re-shaping national "tradition in a way that recognizes the continuous life of Latinos within and around it" (211). My insistence on Vallejo's global perspective, and my argument that this globalism is integral to a Chicana/o literary nationalism, responds to this re-shaping project Gruesz heralds. While Vallejo might not have called himself a Chicano, even if the term had been available to him, he is indubitably a vital and significant part of Chicana/o literary history. If scholars are adequately to reconstruct that history we must think beyond the artificial unity imposed by descent and ethnicity, toward a nationalism that accounts for the historicity of nations, their material effects over time, and how Chicana/o narratives have responded to them.

The force of historical narrative to express a nationalism grounded in economic and political principles becomes clearer when we analyze how Bancroft and Vallejo wrote about history. 
Consider this passage, which appears in a marketing pamphlet promoting Bancroft's Works:

[T] he true wealth of a nation lies in its accumulated experiences, its storehouses of knowledge, and the hearts and minds of a free and intelligent people. These are the kind of acquisitions that history encourages. ... What is a nation without history - without its experiences placed on record to be preserved in an enduring form? ... It is one of the strongest instincts of man thus to remember and preserve, to recite or read, the doings of his forefathers.... Some histories have no beginning, no clearly defined starting point, being obscured by the mists of antiquity; others have knowledge of the nation's inception, the causes that engendered it, and the hour of its birth. (Historical Works 4)

Although no specific author is attributed to the pamphlet, we do know that all texts emerging from Bancroft's workshop underwent a thorough corporate authorship and revision, so it is safe to say that Bancroft would have had a large hand in articulating the above sentiments. ${ }^{6}$ Notice the clear allusion to Adam Smith's Wealth of Nations (1776), the elision of historical data with "acquisitions" to be kept in "storehouses" and then distributed to foster the "development" of a nation. Compare this understanding of history with Vallejo's historical philosophy expressed in a letter to Enrique Cerruti, Bancroft's assistant who took Vallejo's dictations:

Es muy possible que el Sr. Bancroft encuentre 'que los datos que U. le ha enviado estan en choque con cuanto han escrito otras personas;' pero ¿que hacer amigo mio? Todo cuanto he informado á U. estoy dispuesto á probarlo con documentos fehacientes y autógrafos que corroboren mis asertos. Se trata de la historia de este país (Alta California) y es necesario ser verídico é imparcial, haciendome ésto recordas las palabras de Ciceron que decía: "la historia es el testigo de los tiempos, la vista de la memoria, la luz de la verdad, el mensajero de la antigüedad.",

Vallejo avoids economic metaphors and locates the truth of history not in particular facts or dates (which function as engines of progress for Bancroft) but in its rhetorical value as a messenger from the past. Bancroft's insistence on an austere, objective style puts him squarely in line with post-Civil War historiographic developments in the US. As Peter Novick notes in That Noble Dream: The "Objectivity Question" and the American Historical Profession (1988), after the 
war American historians, influenced also by academic historical traditions in Germany, moved away from the ornate, highly personalized styles of amateur historians such as Walter Prescott Webb, Francis Parkman, and Vallejo (42). Therefore, it is possible to read Bancroft and Vallejo's stylistic differences in the context of larger historiographic trends, but in so doing we must also consider how these stylistic differences speak to evolving philosophies of the nation and articulations of ethnic identity.

My argument for the primacy of nationalism as an interpretive mode for Chicana/o literary studies rests upon the distinction between Bancroft's and Vallejo's philosophies of history: history as a function of the economic consolidation of national identity, and as a rhetorical link to the past. In the former position, Anglo-American nationalism is tied to the efficiency of capitalist modes of production and the integration of the national economy in post-Civil War America. Bancroft enacts this in his modes of textual production and his publicly stated views on authorship and writing. In the latter position, nationalism emerges as a function of shifting discursive positions that Vallejo takes with regard to the past. He becomes the voice of a textual national community that recognizes its porous boundaries, its lack of centripetal force, and its contingent existence in relation to other nations. Thinking in nationalistic terms allows us to understand the two texts' fundamental political differences without applying anachronistic conceptions of race and ethnicity to their authors. Nations, race, and ethnicity change over time, yet they remain definitive arbiters of ethnic and cultural belonging, adumbrating not only ethnic, but also economic identifications and conflicts. When viewed in relation to each other, we can see patterns of tension and identification developing in Bancroft's and Vallejo's texts in ways that potentially complicate our received notions of Chicana/o community and continuity. I begin my analysis by examining Bancroft's Works, because Vallejo's text emerges in response to Bancroft's project. I focus my discussion in two domains: the mode of Bancroft's textual production, which is accretive in nature and mirrors the expanding national economy, and his literary relationship with Vallejo, which illustrates the uneasy and tenuous position of Mexicans in Anglo society.

Bancroft, a seasoned bookseller by the 1860s, began his endeavors in historical narrative by amassing a huge collection of books and archival materials. Historical Works, the marketing pamphlet cited earlier, describes his library:

The field thus covered [by Bancroft's collection] is equal in area to one twelfth of the earth's surface; and we venture to 
assert, that never since the world was made, have the early annals of any nation or important section been so thoroughly, so conscientiously, and so intelligently gathered. [Bancroft] alone seized upon the occasion, and stepped in and accomplished the task at the only time and in the only way in which it could be thus so fully and successfully accomplished, and that timely labor of such quantity and quality has never been performed by any other people. (5)

Here we see reflected ideologies of the US's Manifest Destiny to continue its territorial expansion. Embedded in the pamphlet's rhetoric of size is also the assumption of Anglo-American supremacy in strength, organization, and intelligence. The belief that an Anglo-American man is best suited to giving coherent, rational shape to a body of disparate materials is further developed in Bancroft's own descriptions of the writing of the histories.

Although Bancroft claims that there is "no particular system or method" to his writing, when he speaks of writing he does so in language that clearly reflects the values of breadth, efficiency, organization, and production described above. His writing system "applies only to the accumulation and arrangement of evidence upon the topics of which I write, and consists in the application of business methods and the division of labor to those ends" (Literary 331). Bancroft and his team understand writing as an act of winnowing and arranging "precious grains" of historical information, choosing not to acknowledge that the very act of winnowing and the business methods he perceives as value-free are in fact elements of style and ideologically-inflected method (Historical Works 7). When Bancroft speaks of style at all, he speaks of it as an afterthought. The work of authors, in his analysis, is to collect, organize, and dispense evidence in whatever "natural or acquired style" they choose (Literary 330). Style is not a value for Bancroft, but facts or historical knowledge-that which is tied to the economic development of a nation-are extremely valuable. Writing history makes money. "[T]here is palpable and direct money value in [Bancroft's project] for the nation," Historical Works assures us (7).

Bancroft and his History Company use the language of business to describe the project. Fact, or raw materials and finished products, holds value for Bancroft far and above the human element of style, or labor. We see this valuing of product over labor in Bancroft's mode of constructing the texts, which emphasizes "business methods" and the efficiency of a "division of labor." Bancroft describes this division of labor in Literary Industries; 
Historical Works also describes the division, and countless contemporary articles detailed it as well. The first order of business was to index the library so that relevant material could be found quickly. Then, when beginning a particular volume, another set of employees would compose "rough material," abstract notes about a given topic culled from the indexed references. Another group of writers arranged and revised the "rough" into a narrative with some chapter divisions. Finally, Bancroft rewrote and revised what his employees had constructed.

Bancroft's system worked fairly well, but it engendered two major problems for the historian that have some bearing on how we are to understand Vallejo's text in relation to Bancroft's. Both arise from Bancroft's business methods, the first from how he chose to finance his project and the second from his methodical division of labor. To continue collecting materials and paying employees, Bancroft decided to sell subscriptions to the Works, a decision which marked the beginning of a long barrage of critiques, criticisms, and disregard that hounded Bancroft nearly until his death. In the first place, eminent figures such as Charles Darwin and Oliver Wendell Homes who had praised earlier volumes were upset when their praise was used to sell subscriptions to later volumes they had never seen. ${ }^{8}$ Coupled with the perception that he had taken advantage of personal favors was a growing unease within the EAST COAST literary establishment over Bancroft's success. In his memoir "Literary Industries" in a New Light, Bancroft's head librarian Henry Oak describes how literary men in the East, "men of more brains than money," were jealous of Bancroft's success. Some felt that such a project as Bancroft proposed, and the manner in which he proposed to carry it out, could "be little better than trash," yet it was proving to be quite good and profitable (12).

The EAST COAST establishment's criticism gained new force, however, when several of Bancroft's employees began publicly claiming authorship for many of the Works' volumes. These writers claimed that Bancroft's much vaunted "division of labor" was a sham: that while it may have been the original intention, in actual practice employees did much of the work on their own. ${ }^{9}$ While Bancroft's detractors accused him of stealing their work, the matter was purely a business issue for Bancroft. He maintained that his employees were made to understand at the beginning of their employment that all they produced belonged to Bancroft to use as he saw fit, and that they were on his payroll, operating under his direction and using his resources. Beyond a purely legalistic argument, Bancroft felt that the ends justified the means. "I have been able to accomplish thoroughly in fifteen years what 
[the more limited historian], quite as zealous, industrious, and able as myself, has done superficially in twenty-five years, and what he could not have done as thoroughly as myself in half a dozen lifetimes," he asserts in Literary Industries (335). In putting all his faith in the objectivity of business methods to distill pure truth, Bancroft flatly refused to see any truth in his detractors' claims. In confusing his right to publish their work with their claim of authorship, Bancroft invited a barrage of critiques that led many people to assume that the entire Works was the product of hired hands.

Despite a long period of disregard, Bancroft's histories are today seen as excellent sources; with their clear, linear narrative, endless footnotes, and exhaustive explorations of multiple points of view, they are nothing if not scholarly. Nevertheless, the image of Bancroft we have after considering his texts in light of his business methods troubles the image of the imposing AngloAmerican historian that Genaro Padilla sees as oppressing Vallejo with his texts. Vallejo, a prominent and well-respected man, would have been on equal footing with Bancroft, who-wealthy and well known as he was becoming-was not without his serious detractors. Although their relationship was not one of dominance and subjugation, Bancroft's writing reveals a marked ambiguity about the Mexican-American population he so strongly supported. Bancroft was very vocal in his opinions that the US had done wrong by its Mexican population; his assertions led the Society of California Pioneers to revoke his honorary membership. ${ }^{10}$ Likewise his personal and public writings reveal a profound regard for Vallejo. As late as 1915, Bancroft sent Vallejo's son Platon a draft of a speech in which he wrote of the father, "I never met a man of purer patriotism or kinder heart." Nevertheless, his published writings and unpublished correspondence present a slightly more complicated picture.

In Literary Industries, for example, in describing the enthusiasm with which Vallejo took up the project of helping him, Bancroft writes that the history "was a work in which [Vallejo] was probably more nearly concerned than the author of it. If I was the writer of history, he was the embodiment of history. This he seemed to fully realize" (212). The fact that Bancroft and Vallejo barely spoke the same language problematizes Bancroft's assumptions about what Vallejo understood. Even more troubling, however, is the positing of Bancroft as the thinking writer above Vallejo, the bodily actor. Both moves involve the assumption of a position as privileged interpreter, within which is imbricated a sense of superiority, that makes the reader doubt Bancroft's claims to historical objectivity. 
The subtle racism and implied Anglo supremacy of Bancroft's description of Vallejo is self-evident; ${ }^{11}$ less obviously problematic are the ways in which Bancroft's position permeates contemporary scholarship on the testimonios. Vallejo's approach to historical truth and his first-person narrative leads Genaro Padilla to assert that Vallejo was anxious to maintain "personal control" over the Recuerdos (89). Padilla assumes that Vallejo's self-identity was inextricable from the act of his writing and this is, I contend, equally as problematic as Bancroft's insistence that he was the writer of history that Vallejo embodied. Both positions assume a transparency between Vallejo's history and his life, thus ignoring the materiality of the text and denying Vallejo the ability or the chance to speak to anything besides his personal experience. In other words, Padilla's reading of Vallejo sees the Californio as just as much an embodiment of history as Bancroft's. To be fair, Padilla's reading does put Vallejo in the context of amateur literary historians of the late nineteenth century who, Novick notes, wrote out of personal feeling or a sense of moral obligation, making "no effort to achieve the authorial invisibility, which had become normative in the late nineteenth century" (45). At the same time, however, Padilla allows for Vallejo to do no more than write from a sense of moral outrage, when we can also view his text as gesturing toward larger historiographic debates over the nature of the historic text and the possibility of objectivity.

Padilla's argument rests upon the assumption that Vallejo understood his text as the vehicle through which he could speak truth to power, offer a counter narrative. Padilla makes much of, and even takes the title of his own book from, Vallejo's supposedly telling Cerruti that although he is willing to dictate his memoir, he "will not be hurried or dictated to. It is my history, and not yours, I propose to tell. ... If I give my story it must be worthy of the cause and worthy of me" (Literary 211). This scene appears in Bancroft's memoir, but archival evidence reveals that Vallejo's actual words were slightly less declamatory.

While archival evidence does not reveal Vallejo denying he ever spoke such words, it does reveal similar statements with, however, decidedly different implications, suggesting that Bancroft altered Vallejo's speech to serve his own ends. Bancroft gets this scene from an 1874 letter written by Cerruti to Bancroft in which Cerruti informs him that Vallejo does indeed have many documents, but they are difficult to read for they have been half eaten by moths. More infuriating to Cerruti, although, is Vallejo's reluctance to let the documents travel to San Francisco. Vallejo wants Cerruti to examine the documents at Vallejo's home, carefully "pues el dice que la historia debe escribirse despacio y no a la 
yankee sentado sobre el caballo."12 The moment shows up again in Cerruti's memoir, Ramblings in California: The Adventures of Henry Cerruti (1954) (54), combined with parts of another letter, suggesting some authorial invention on Cerruti's part. In neither his letter to Bancroft nor his memoir, however, does Cerruti make any reference to Vallejo calling his Recuerdos "my history, not yours." Vallejo insists that he must tell the history in "[his] own way" (Ramblings 54), but he does not say that he must tell his own history. This discrepancy may seem minor, but it is significant because we know that in viewing Vallejo as the embodiment of history Bancroft clearly objectified him and did not fully grant him the ability to think rationally, analytically, or creatively about the narrative he was writing in "[his] own way." Bancroft assumes a position of objectivity in all his writings, but putting words in Vallejo's mouth merely makes his point about the difference between writing and embodying in a different way. If Vallejo is writing "[his] history, not [Bancroft's]," then he is not really thinking, but simply acting.

Bancroft thinks that Vallejo is writing his own history, while Vallejo thinks that he is writing history in his own way, a difference of opinion (or semantics) that bears heavily upon how each man conceived his historical project. Bancroft viewed Vallejo's narrative as a highly personalized, subjective account based, at times, in opinion more than fact; again we can recall here the emerging "professional" historian, described by Novick, which Bancroft clearly sees himself as (Novick 42). Vallejo, on the other hand, both in the Recuerdos and in his private correspondence, is nearly obsessed with objectivity. In a letter to Cerruti, he asserts, "yo ni he tenido, ni tengo la intencion ni el deseo de deviarme de la verdad." 13 And in the "Prologo" to his Recuerdos, he writes, "Mas yo no me propongo otro fin si no legar á la posteridad una historia exacta de los hechos tales cuales han acontecido, y en que cada actor, cada pueblo, y cada ciudad figuren segun sus proprios meritos" (I. iii/iii). ${ }^{14}$ Vallejo is very concerned to represent what he understands as truth. To read his work as subjective, or to think Vallejo understands himself as bearing a synechdochal relation to the history of Alta California, obscures the value of this truth and lessens the force of the arguments we can glean from his text: namely, that historical texts necessarily reflect authorial bias, and that the self is composite, not in the sense that Sánchez imagines it as a communal identity, but rather in the sense that it is contingent and textually constructed.

Vallejo's Recuerdos are comprised of law, letters, historical facts, and his own musings on a range of topics. Vallejo calls it a "compendio de la verdadura historia de California" (IV. 422/320). ${ }^{15}$ 
The choice to call it a compendium gives us some idea of the tensions that underlie the text. While the Recuerdos are exhaustive in scope, a compendium is still a summary, and yet Vallejo asserts that the history is "true." However, any abridging - any narrative, in fact-involves authorial choices and biases, Vallejo's protestations to the contrary notwithstanding. Although Vallejo makes many anxious gestures toward truth, his use of the word compendio suggests that he was not so naïve as to think his text was bias-free, or that any text could be, and he certainly does share his opinion on a variety of topics quite freely, which Bancroft does only to adjudicate among his own documentary evidence.

That Vallejo and Bancroft take different approaches to voicing their own opinions within their narratives suggests both a difference in their view of historical truth, as I have suggested, and a difference in their understanding of the relationship between themselves and their national economies. Bancroft's labor dispute with his employees over the question of authorship, and his attempts at complete self-negation in the Works, suggest the elision of individuality and the alienation from labor characteristic of an expanding capitalist economy. On the other hand, Vallejo's very present self within his text and his reliance on letters, documents, and relationships with others in the construction of his narrative suggests the paternalism of the Spanish hacendado, which operated within a market economy structured around the patriarchal family. In this system, peonage was class-based and hereditary (similar to the southern US plantation economy), the landowner was physically responsible for his employees, and wage labor was a foreign concept.

Their disparate approaches to historical truth denote also a difference in the textual construction of self. Bancroft assumes his self to stand outside any discourse as a perceiver and processor of information. Vallejo, however, argues that the self as a subject is constructed via a variety of nationalistic, legalistic, and moralistic discourses. In other words, history does not exist outside our selves; we construct it when we write it-thus confusing the notion of truth, especially historical truth. When Vallejo quotes Cicero saying, "history is the light of truth," he is asserting not that knowledge of the past is fact-based and irrefutable, but that how we construct our narratives of the past constitutes a truth we tell about ourselves. ${ }^{16}$ Vallejo's constant references to and obsessive concern with truth can be read not just as an anxious attempt to offer counter narratives to the many racist, Anglo histories of California in circulation at the time of his writing, but also as recognition of the impossibility of knowing the truth and the past. 
What do we make then of this tension in Vallejo's narrative between objective truth and the textually constructed self negotiating simultaneous truths? Vallejo may tell us that he believes "que la historia debe ser tal cual Ciceron la pintó 'lux veritatis, atque testigo temporum"' (Recuerdos I. 45/33), but then he also tells us that history lies. ${ }^{17}$ At several points in the narrative, Vallejo makes overt, emphatic, and performative references to truth and assures his readers that all he says can be verified in records, but his claims to truth become slightly shaky when he veers into the realm of memory. In Volume I of the Recuerdos, Vallejo tells of the 1815 arrival in Monterey of Governor Solá from Mexico, a time of growing tension between the colony and its Spanish rulers. He describes the political tensions between Spanish loyalists, such as Solá, and those who desired Mexican independence. Vallejo then describes the ball held in Solá's honor in detail from a letter written 60 years after the fact in 1875. He claims that although the letter relies on memory, it "es el reflejo de los hechos, modo de pensar y costumbres regian entre nosotros en 1815" (I. 130/95) ${ }^{18}$ Although the letter may be inaccurate in some ways, it has historical value for Vallejo because it adumbrates a subjective truth.

Vallejo views historical memory, that which purports to objectivity, as much less benign in its approximation of truth. Vallejo's tone in telling how California's San Quentin earned its name is dismissively jocular, yet the anecdote gives Vallejo occasion to meditate on the transmission of stories through time and how linguistic details convey depths of meaning in their misinformation. Quintín was a lieutenant of Chief Marín who ruled the Licatiut that blocked Californio settlement north of San Francisco through violent warfare and occasional murderous invasions of the Californio villages there. After a particularly bloody battle between Solá's and Quintín's forces, the Californios took to calling the place where it occurred the Punta de Quintín. Vallejo writes:

[E]staba reservado á los norte Americanos cambiar el nombre de ese lugar y llamar á la "punta de Quintín" "punta de San Quintín"; qual sea el motivo que haya inducido á los norte Americanos efectuar tal cambio, lo desconosco, pero creo que puede atribuirse al hecho que habiendo gran numero de ellos llegado á California con la creencia de que los habitantes de este país eran sumamente católicos, con el fin de congraciarse con ellos añadian "san" á los nombres de los pueblos ó aldeas que visitaban. Recuerdo haber en distintos occasiones oidecir "Santa Sonoma," "San Monterey," y "San Branciforte" y guiados por esa costumbre le añadieron el San 
al nombre de Quintín; sobre esa conducta no hago comentaría, pues admito el dicho latino "de gustibus non est disputandum." Si punta de San Quintín les agrada mas que el simple "punta de Quintín” que se queden con su fantasma y su santo, seguro que yo no se los envidio. (I. 148/190) ${ }^{19}$

While Vallejo blithely comments that there is no quarreling with taste, what he is really describing here is the way that language misinforms and can be deployed to erase memory and enforce a hegemonic view of the past. In calling the Punta de Quintín "San Quentin," the Americans are excising the Licatiuts from the region's cultural memory and creating a false and condescending "Catholic" past for the place.

Contained within this seemingly lighthearted story is an argument about the work of history: claims to veracity aside, all historical narrative is in some way an act of violence, erasing one memory to replace it with another. We can read Vallejo's claims to truth as claims to a truth that moves beyond historical fact and transcends the content of his story. The disjuncture between word and deed we see in the story of the Punta de Quintín becomes increasingly pronounced as Vallejo moves through his narrative. The more he recognizes the linguistic manipulation of others, the more his text bears the formal brunt of his realizations. Although Vallejo continues to use his recollections as evidence after this discussion of Quintín, his invocations of memory begin to be coupled with abrupt generic shifts that can be read in conjunction with the text's growing dissatisfaction with and alienation from both the US and Mexico.

Once the text moves into the time of which he has personal memories Vallejo begins to intersperse his narrative with personal recollections, seemingly at random. He remembers his interactions with Solá, and regales his readers with anecdotes about Father Magín and other Mexican priests in the region (I. 257/194). These incorporations of the personal would seem like irreverent touches if they were not always coupled with discussions of political conflict. Immediately after the story about Father Magín, Vallejo begins writing of Mexico's independence from Spain and the tricolor flag of the fledgling Republic. The pattern of political conflict spurring a personal memory and then motivating a generic shift continues as we move through the Recuerdos, but around the time of Vallejo's marriage we get the added element of literature, literary criticism, and analysis.

At Vallejo's wedding, Governor Echeandía informs the newlywed that he, Vallejo, will have to leave immediately after the wedding dance on a military campaign. As with the emergence of 
Mexican independence in the text, the announcement of a new political conflict inspires the invocation of memory: "Tengo aun presente el brindis del señor Echeandía, y creo oportuno reproducarlo, pues aunque desde entonces han transcurrido cuarenta y tres años todavia lo recuerdo con placer" (II. 190/155). ${ }^{20}$ Vallejo goes on to quote the toast, and of course we must take his claims to faithful reproduction with a grain of salt. What is interesting here, though, is not whether Echeandía actually said what Vallejo remembers, but that this invocation of personal memory is coupled with a love poem to Vallejo's new wife. Vallejo depicts himself composing the romantic poem, replete with passionate embraces and eternal kisses, extemporaneously. Padilla discusses this moment in the text also, commenting that the "lavish prose in this section discloses Vallejo's ease with-and in-the past" (95). But this is not all prose, it is poetry, sprung out of personal recollection-a double generic shift instantiated by the emergence of political conflict in the narrative.

The wedding scene is not the first moment in the Recuerdos where Vallejo places importance on literature, specifically poetry, but it is the first instance where literature is coupled with the invocation of memory and political conflict. These moments in the text suggest that literature is tied, for Vallejo, to the inevitability of political conflict, and they show how conflict is imbricated in the instability of truth, language, and memory. Poetry also gains importance when Vallejo tells the story of how Don Joaquin Buelna, a Santa Cruz judge, fought off a rumored attack on his person with poems. According to Vallejo, Buelna sent copies of his poems to his supposed attackers who were so frightened of the poetry's power that they gave them to a priest for safekeeping. After relating Buelna's story, Vallejo critiques the poetry, claiming, "Los decimas son pesimas, no tienen ningun merito literario pero á Buelna le acarrearon tranquilidad politica y doméstica; esta prueba lo bien fundado que era el antiguo refrán latino "parva saepe neglecta scintilla magnum excitavit incendium"' (I. 220/ 164). ${ }^{21}$ From this tiny spark, Vallejo takes a great lesson about the power of literature. While Vallejo scoffs at the superstitions of Buelna's attackers, he does not deny that poetry can have significant power.

The moments in Vallejo's narrative in which he appears to be merely analyzing literature or commenting upon someone's literary tastes always link up to moments of political commentary or policy analysis. Vallejo takes pains to emphasize the distance between literary quality and quality of character, institution, or event. Buelna, for instance, is a good man but a terrible poet. Nicolás Alviso's poems commemorating Hippolyte Bouchard's 
pirate raid on Monterey are excellent but the event was devastating (I. 204/152). Don Joaquín Maitorena is not a bad poet but he is a drunkard and represents Alta California poorly in the Mexican Congress of 1824 (II. 19/15). When, in Volume I, Iturbide's government sends Canon Fernandez to Alta California to exact oaths of allegiance to the new constitution from the province's authorities, Vallejo describes him as a handsome man with excellent literary taste, but with a taste also for diplomacy and intrigue, the kind of man who "ha sido causa de tres cuartas de las revoluciones que durante los últimos cinquenta años han asolado Méjico y las demas repúblicas de Sur y Centro América" (I. 284/216). ${ }^{22}$

On the one hand, then, literature and literary analysis serve in the Recuerdos as signs of misrepresentation, deceit, and disappointment. Still, however, there exists a tension between this idea of literature and the positive political power to be had via access to books and education, such as in Vallejo's account of how he faced excommunication by the Catholic Church in order to acquire a library including Voltaire, Rousseau, and other books the Church had banned (III. 111/92). Although Vallejo consistently links literary discussions to either invocations of memory, which are necessarily fallible, or political conflict, deceit, and intrigue, he nevertheless continues to use literary discussions to make complex political and personal points. His discussion of early Alta Californian political life is loaded with poetic analysis. He can only convey his love for his wife through poetic language, and desire for abstract knowledge can be described only through a discussion of the literature he and his friends read.

Vallejo's discussion of the books banned by the Church follows the same pattern of all his literary appeals. Talk of Rousseau and Voltaire is followed immediately by a relation of the scandals of Governor Mariano Chico's administration and Santa Ana's surrender to Sam Houston. Of Santa Ana Vallejo tells us:

Estando el cautivo, relegó al olvido sus gloriosos antecedents, reconocío la independencia de Tejas, y á mayor mengua de la República Mexicana se humiló al gobierno de los Estados Unidos que en despecho de los tratados existents con una república hermana habian azuzado la rebellion de una parte de sus ciudadanos contra el jefe de la República. (III. 127/104) ${ }^{23}$

We see two important things happening in this critique of Santa Ana's behavior. On the one hand, we see Santa Ana deviating from his public image as a staunch defender of the Mexican republic, showing his craven self in his capitulation to the Texans' demands. On the other hand, Vallejo references a duplicity that 
goes beyond just the individual. He points to treaties between the US and Mexico in order to show how the US ignored them. He shows us how what was on paper had no bearing upon what actually happened.

Vallejo treats the 1824 Acta Constitutiva (the Mexican constitution) in a similar fashion. Political conflict in the Recuerdos motivates a generic shift, a move from straightforward narrative to poetry, or a letter, or an anecdote. Similarly, this discussion of the constitution-in which Vallejo highlights the discrepancy between the written word and actual practice-sparks a generic shift in which Vallejo moves from narrative to include the entire text of a law or official political document. In introducing the 1824 Acta Constitutiva, Vallejo comments that very few copies of it survive, and since he considers it important, he will include the entire thing. He predicts that, after reading it, his readers:

$[P]$ odrian juzgar de la manera como ese documento haya influido en el bien estar de la república mexicana, que durante el transcuro de los últimos cuarente y siete años ha sido tantas veces juguete de los muras ambiciosas de algunos hijos rénegados que sordos al grito de angustia ... hicieron sin cesar y sin piedad las entrañas de la madre patria que á ellos debe sus angustias y quebrantos todos. (II. 32/26) ${ }^{24}$

Although the 1824 constitution is inspiring, it is nearly ineffectual. The new government facilitates the rich getting richer and the poor getting poorer while the seven million natives in Mexico "estudiamente se mantenia en la barbarria é ignorancia" (II. 41/34). ${ }^{25}$ This disjunct between word and meaning recalls the slipperiness of language notable in Vallejo's account of how the Punta de Quintín became San Quentin. While that story serves as an example of the ways in which Vallejo appreciates the mutability of literary and historical language, we see here what happens when the mutability of language intersects with attempts to write the nation.

The 1824 Acta fails as a document that delineates the nation. According to Vallejo, none of the things it promised came to pass, and while it set up Alta California as a protected department of the Mexican republic, Mexico continued to mistreat and mismanage the province even more severely after the Acta. The nation, as both an abstract and material notion, holds little significance for Vallejo outside of concrete, economic realities. The documents with which it defines itself prove to be just as inconstant and shifting as the changing place names of the northern frontier. Just as those changing place names spoke to larger political and cultural 
forces at work though language, so does the failure of national documents to create a nation speak to corruption of the Mexican government for Vallejo and the untenability of patriotism or Mexican nationalism as guiding principles in his action.

The Recuerdos display an acute suspicion of national pride throughout. The only time Vallejo experiences "todo el fervor de [su] alma repúblicana" is when he is denouncing Governor Chico for his "hacen alarde publicamente de su desenfreno y desprecío de la buena opinion de las personas virtuosas" (III. 120/99). ${ }^{26}$ When, in the midst of the Mexican-American War, Governor Micheltorena (the last Mexican governor of Alta California) distributes broadsides intended to arouse the Californios to resist occupation, Vallejo calls them documents that "llevan impreso mas bien el sello de la locura que lo del patriotismo" (IV. 303/229). ${ }^{27}$ Vallejo grants that such a thing as patriotism can exist, but calls to take up arms in defense of Mexico will not arouse it in him.

Mexico's inability to govern Alta California effectively serves as the Recuerdos' leitmotif, arising throughout the narrative and sparking abrupt generic shifts or pointed literary analyses. Mexico's failings are due in part to its distance from the outlying territory but also to simple neglect or disregard. At one point, Vallejo tells us, Mexico's President Bustamante, forgetting that he had already appointed a governor to Alta California, accidentally appoints another one. "Pero eso no debe causar admiración," Vallejo assures us, "pues sabido es que los Presidentes de la República Mexicana solo se acordaban de California cuando algunos los visitaban personalmente ó bien por conducto de nuestro disputado haciamos llegar a sus manos alguna carta ó regalo" (IV. 35/26). ${ }^{28}$

Although Mexico may have neglected California in many ways, the central government still managed to send governors and extract resources from the region. The governors were, in Vallejo's opinion, much like the loose living Governor Chico, "en su mayor parte, sujetos desnudos de toda clase de atributos que tienen tendencia á enoblecer á los mandatarios" (III. 172/142). ${ }^{29}$ Vallejo supports the move for Californio independence from Mexico in 1836, resting his political argument-ironically, given his suspicion of laws and treaties - on the immutability of the laws that, he argues, the Mexican governors neglected to follow. A similar tension is notable in Vallejo's rendering of his nephew Juan Alvarado's declaration of independence: "California es libre, y cortará todas sus relaciones con Mejico hasta que deja de ser oprimido por la actual faccion dominante titulada gobierno central" (III. 196/ 164). ${ }^{30}$ While the Californios resented Mexican rule from afar, they nevertheless wanted to maintain ties to Mexico as an equal partner in the federation. 
Between expressing his own lofty political sentiments and relating Alvarado's declaration, Vallejo digresses momentarily into a discussion of the poetry of Castillo Negrete, a lieutenant of then Governor Nicolas Guttiérrez, who was opposed to independence. Vallejo says he does this consciously because "como escritor imparcial me incumbe descorrer el velo de los motibos que indujieron al erudito pero mal inencionado poeta á calumniar a los vencendores de Guttiérrez" (III. 194/163). ${ }^{31}$ By this he means that although Negrete and others justified their behavior to the Central Government by arguing that foreign forces were inciting rebellion in Alta California, in "truth" they harbored personal grudges against those fighting for federal status. Again we see here a discrepancy between literary and personal quality-the poetry is not bad, but the politics, in Vallejo's estimation, are. Even more telling, however, is Vallejo's self-consciousness regarding his digression. He claims it is borne out of an obligation to objectivity; we can also make the case, however, that this sliding between genres in a discussion of Alta California's federal status hints at deeper unease concerning claims to liberty in the form of the nation-state.

Vallejo refers to himself as a "Californio nacido en este bello país que pertenecía á la República Mejicana" (III. 170/140). ${ }^{32}$ We know that he sees California as a space apart from Mexico, and from this reference to himself we see this carries over into his own self-identification. Although he may have understood Alta California as independent, that does not indicate he thought of it as a separate country. Indeed, Vallejo's suspicion of narrative (shown in his generic indecision), language (shown in his continual emphasis on the distance between word and reality, as well as in his literary references), and nations (shown in his overt diatribes against both the US and Mexico) indicate a deep distrust of nationalism and its constituent narratives.

That distrust crystallizes in Vallejo's discussion of the HijarPadrés colony. The colony was a subsidiary of the Compañia Cosmopolitana, which sought to export Californian products. Its directors desired a kind of military authority in California while the Californios wanted them to be merely civil directors. The company argued that with military control could they fully bring about their plan of liberation through trade for Alta California. Vallejo and others felt that the colonization plan was really a plan to plunder the missions under the protection of the highest government authorities. According to Bancroft, however, while it appeared that "certain members of the colony under the leadership of Padrés were engaged in plots to secure the territorial government by force" (History III. 280) there is "no real evidence to support 
the claim that the colony was out to despoil the territory" (III. 265). Bancroft notes that colonization had long been thought to be the best way to settle Alta California and many "intelligent men" had long ago realized the impracticality "of attempting to continue the old monastico-missionary régime" (III. 264). Vallejo disagreed with Bancroft and saw the colony's deployment of liberation rhetoric as a manipulation, for its own personal gain, of Alta California's yearnings for independence (II. 386/315). Patriotism is problematic for Vallejo, as are calls to liberty in the voice of the nation-state. Given his reliance on rhetoric to adumbrate historical truth, Vallejo's suspicions of nationalist rhetoric suggest that the nation must have a strong economic and juridical base. As we explore his writings on trade and monetary policy, we begin to see how this base is, for Vallejo, international in scope and so destabilizes any notion of monolithic, isolationist nationalism.

From the beginning of its Spanish settlement Alta California had global prominence, and since the Mexican declaration of independence from Spain in 1810, the major governments of the world had been seeking ways to insert themselves into Mexico to take advantage of its relative weakness and exploit its resources. Vallejo saw the world's intrusion in Mexican affairs as one of the key factors retarding its progress, yet he also recognized that a healthy world trade was necessary for Mexico's and Alta California's success. For Vallejo, the key to political strength did not lie in passionate defenses of patriotism or empty calls to liberty but in finding a way to be open to the world and prosper from what it had to offer. Unfortunately, he found, as he did with the Hijar-Padrés colony, that being open to the world also meant making oneself vulnerable to it.

Vallejo warmly welcomed immigrants from the US, admiring their ingenuity and work ethic. In the Recuerdos he writes, "La llegada de tanta gente forastera llenó de contento á nosotros los arribeños, que veiamos con sumo agrado que desde el otro lado de la Sierra Nevada vineron á sentar sus reales entre nosotros numerosas companias de gente industriosa" (III. 384/307). ${ }^{33}$ But, he also held that the US rule did not benefit the Californios. In addition to his own fiscal losses, Vallejo lamented in the Recuerdos, "Que lindo hubiese sido, si la decantada ilustracíon que los Americanos del norte han traido á California no hubiese pervertido nuestros patriarcales costumbres, y relajado la moralidad de la joventud" (I. 65/47). ${ }^{34}$ He sees moral decay as an outgrowth of the gold rush and so many aggressive adventurers coming to seek their fortunes in California.

Vallejo's distrust of foreign influence was not limited to Anglo immigration to California, however. There is no love lost 
between Vallejo and the French, whom he sees as "un pueblo esencialmente fanfarron [que tienen] el ser palanzana [como] su segunda naturaleza y [por quien] es muy difficil que en pais estranjero olviden las costumbres de su patria que son tan distintas de los de los démas pueblos" (III. 279/234); ${ }^{35}$ and he sees the Masonic factions in Mexico as "instrumentos de una politica estranjera," responsible for the civil wars retarding Mexico's progress (II. 55/45). ${ }^{36}$

Vallejo's feelings about a perceived global threat to Mexican sovereignty highlight his policy analyses for Alta California now that "la civilizacíon europea á pasos agigantados se [los] estaba viniendo encima" (III. 238/202). ${ }^{37}$ Like literary analysis, policy analysis plays a large role in the Recuerdos, coming often in the form of inserting the entire text of actual laws as well as his own proposed laws, coupled with a brief discussion of the pros and cons of the legislation. A closer look at Vallejo's ways of writing about international relations and trade offers some insight into his articulations of nations and nationalism.

The Californios had long had a global view of the world. Early in the nineteenth century, Russia had established a stronghold, near what is now known as the Russian River, from which they traded fur with the native tribes and the Californios. Vallejo had negotiated with the Russians to purchase arms in the 1830s, continued negotiations with them as the Californios sought to curb Russian smuggling throughout the decade, and maintained business and political relations with them after he had been appointed to the northern frontier. Vallejo dealt similarly with representatives from various countries and business enterprises. One of the main Californio complaints when they declared independence from Mexico was the restrictive and backwards trade laws Mexico imposed upon them that hindered them from fully thriving and developing in a global market. After the declaration of independence, Alta California passed a law for itself that would have encouraged free trade with the rest of the world. Vallejo includes the entire law, commenting, "En el breve transcuro de tiempo en que la Alta California permanecío separada del gobierno de la madre patria que tanto nos habia oprimido ... brindose ... á los ciudadanos del universo un campo extenso para prosperar á la sombra de leyes sabias y previsoras" (III. 211/ 179). ${ }^{38}$ That prosperous period, unfortunately, was short-lived.

Although free trade had a short life in Alta California, Vallejo, ever forward-looking, continued to write and promote policies encouraging development. He writes, prints, and distributes his own plan for increasing the population of the northern frontier and revitalizing the treasury. He argues that, since the Republic is 
unable to provide resources to Alta California, "los que sentimos mas immediamente estos males nos empreñemos en el remedia si es que estamos animado de un vivo deseo por la prosperidad nacional y tenemos cuenta asi mismo con nuestros particualres intereses" (III. 344/279). ${ }^{39}$

In these fiscal propositions, Vallejo refers to a nation but only in the context of economic prosperity and not to any abstract or ill-defined sense of kinship. We should note that the "nation" in his proposal is separate from the Republic, so when he speaks of the nation he is not speaking of Mexico. We know that Alta California was never an entirely separate state, although Vallejo refers to it as the Free and Sovereign State of Alta California, and we know that complete independence was never desired, only equal federal status. So what is the nation for Vallejo? What does he mean when he speaks of national prosperity, and what is the political form that he imagines for himself and his fellow Californios?

In telling the story of Governor Micheltorena's negotiations with Commodore Jones of the US Navy (who, under the impression that the US and Mexico were already at war, had mistakenly taken command at Monterey Bay), Vallejo reconstructs the private meeting putting these words in Micheltorena's mouth: "No hacer la felicidad de las naciones las muchas leguas de estension, pero si la hacen la población y el orden; ... son mas utiles á los Estados los sabios establecimientos que la conquista y ... el fomento es el alma se la subsistencia y no el regimen coactivo" (IV. 323/245). ${ }^{40}$ Vallejo goes on to heartily approve of Micheltorena's realizations. Since Vallejo was not at the meeting and can only reconstruct it via hearsay, we can read this definition of the national good as Vallejo's own, especially since he praises it so highly. In this understanding, the nation is not defined by land but as both a discursive - in terms of law-and economic enterprise allowed free development in the good faith of its people.

Vallejo's understanding of the nation gives us even greater insight into his enthusiastic support of the 1827 report of the Junta de Fomento de Californias (Committee on Californian Development) of the Mexican Congress. Their plan called for the formation of the Compañía Asiático-Mexicano, which would foster trade between California and the Pacific Rim. Had it "se hubiese llevado á debido efecto hubiese dado al Puerto de Monterey gran importancia maritima," Vallejo tells us (I. 300/ 230). ${ }^{41}$ Vallejo includes all 64 articles of the proposed legislation including detailed information about tax concessions, the privileging of Californian products, attendant colonization plans, and routes of import and export in which Monterey serves as the 
gateway to the rest of Mexico. Vallejo thinks it an excellent plan and is sure that had it not been for Mexico's civil unrest the law would have been put into effect and California become one of the most prosperous points on the Pacific Rim. In his endorsement of the Asiatic-Mexican Company Vallejo offers an example of what an open and prosperous engagement with the world could be. In rhetorically separating California from Mexico with regards to economic prosperity, here and in his dispatch concerning the treasury, Vallejo shows how a worldly engagement can be predicated less on land mass or war and more on discursive, economic community.

By including actual laws and proposed legislation in the Recuerdos Vallejo delimits his imagined community, whichbounded by law-is necessarily discursive. Legislation concerning the Asiatic-Mexican Company never comes to fruition, as is the case with several of the laws he includes. By counterpoising these with laws that actually do come to pass, and by pointing to the ways in which the US, Mexico, and their agents disregarded other laws, Vallejo points to the distance between what is written and what happens. The distance between law and action is analogous to the distance, or slippages, of language, history, and narrative we have seen throughout this analysis, in Vallejo's generic shifts and in the importance he places on literature as a constitutive component of his history. In those cases, however, Vallejo's focus is the language, while in his discussion of law his focus is on action. The difference between language and action, for Vallejo, signals a shift in his conception of community: the literary analyses are tied to intra-communal reflection while the legalistic moves later in the Recuerdos reflect an extra-communal focus. That is, emphases on law-both real and imagined-delineate the global shape of a changing Californio consciousness; that these laws tend to be related to trade suggest an economic understanding of the global.

Because the trade legislation Vallejo discusses either never comes to pass or is short-lived, we might be tempted to view it as just one more way in which the Recuerdos narrate loss. Yet, in relating what did not happen, Vallejo offers us the textual possibility of what could happen. "Que lindo hubiese sido," he says, how beautiful it would have been, if the Californios could have had "American" progress without the attendant moral degradation (I. 65/47). The grammatical structure of this counter-factual-the imperfect subjunctive-is reflected in the narrative structure of the text, especially in the discussion of law.

The generic instability of the Recuerdos signals unease about politics, language, and history. The text moves back and forth across genres, never settling comfortably in one place for 
long. The lure of the borderlands is seductive here; we could say that in its generic indecision, the text lives in the margins troubling the narrative center, marked by a text like Bancroft's. We could say that in their narratives of loss and oppression, the Recuerdos speak truth to the oppressive lie of Anglo-American historians like Bancroft. But to do that would be to ignore how Bancroft tried to give voice to the Californios, and it would also be to ignore the very troubling aspects of Bancroft's text; it would do a disservice to Vallejo's work.

Vallejo is not simply a voice from out of the shadows illuminating early Chicana/o experience. The differences between Vallejo's and Bancroft's histories of California are much deeper, and far more significant. Bancroft's history adopts a depersonalized, authoritative, fact-driven tone. Concerned with an accurate representation of the past, the history documents every claim it makes, the body of the text resting on inches of footnotes at the bottom of each page. Assured of its rightness, the history moves forward like a well-oiled machine, absorbing conflicting narratives within itself and reproducing itself several times over in 39 volumes. The text, its mode of production, and its marketing reflect Anglo-American capitalism and nationalism at the turn of the twentieth century. But Bancroft's Works is not without its problems. As we have seen, he was severely criticized for his "business methods," supposed biases, and lack of objectivity.

Vallejo's Recuerdos exploit these fissures in Bancroft's austere, historically objective façade. While Bancroft's text moves forward in an orderly fashion, Vallejo moves back and forth in time, discussing the US's 1848 occupation of California one moment and Junipero Serra's eighteenth-century deeds the next. Far from Bancroft's consistent and predictable prose stylings, Vallejo moves deftly from literary analysis to history to poetry in one page. If we grant that Bancroft's text reflects late nineteenth-century Anglo-American capitalist nationalism, and we grant that the critiques of Bancroft's text can also be read as critiques of the same, then we must also read Vallejo's Recuerdos, in their exploitation of Bancroft's fissures, as a critique of Anglo-American capitalist nationalism.

"Que lindo hubiese sido" to have had progress without moral decrepitude, to have had free trade in Alta California, to have had an Asiatic-Mexican Company. "Que lindo" if Hijar and Padrés had really meant to liberate Alta California, if smuggling could have been curtailed, if the US had honored the Treaty of Guadalupe-Hidalgo, and if Castillo Negrete could have lived up to the promise of his poetry. Yes, Vallejo is angry, and yes, his stories of loss, oppression, and racialization are important to study, 
but it is also important to look at how he tells these stories. The different strands of his argument necessitate different genres, and the text's constant shape-shifting reveals not a voice on the margins but a voice with global aspirations. Vallejo's Recuerdos attempt to encompass everything - what happened, what did not happen, and what it means when the two do not match up. The text, thus, offers not just a narrative of loss but also a narrative of future possibility. Ignoring this future possibility means ignoring half of Vallejo's narrative; it also means remaining entrenched in ways of reading that refuse to see invocations of the nation as anything other than an ethnic entanglement or capitalist imperialism. Vallejo's attempts may not be fully successful, but he is clearly trying to articulate a nationalism predicated not on ethnic isolation and oppression, but on global engagement bounded by trade legislation dedicated to the common good, aims reflected in his approach to historical narrative. Reading him in this light suggests a new, expansive origin story for Chicana/o literature: one that encompasses a range of Chicana/o subject positions, grants Chicana/o concerns philosophical weight, and views them as integral to the development of US literature while situating them in a decidedly transnational context. Such a strategy opens a world of possibility for rethinking Chicana/o literary history as we come to realize that it always has been global in its scope.

\section{Notes}

I wish to thank both the Bancroft Library at the University of California, Berkeley and the University of California's Institute for the United States and Mexico (UCMEXUS) for their generous financial support, which allowed me to complete the research for this article.

1. Alan Rosenus's excellent biography General Vallejo and the Advent of the Americans (1999) provides multiple examples of this view of Vallejo, including Vallejo's dispute with his nephew Juan Alvarado, governor of California in 1841 during the negotiations with Russia over the fate of Fort Ross. Vallejo, going against the wishes of Mexico's President Bustamente, wanted permission to purchase the fort in order to prevent the Russians from dealing with the Americans. Alvarado felt that his uncle was merely trying to consolidate his own power and refused to grant permission (Rosenus 26).

2. The Treaty of Guadalupe-Hidalgo, which ended the Mexican-American War in 1848, secured land titles granted by the Spanish and Mexican governments. In 1850, California was admitted to the US as a state, and in 1851 the US Congress passed the California Land Act. Historians are nearly unanimous in their opinion that this law-which required claimants to prove their titles before a Board of US Land Commissioners and set up arcane and complicated rules for doing so-flagrantly defied the Treaty and was a legalistic ruse to wrest land out of 
Mexican and into Anglo hands. The Act of 1851 required claimants to prove their title before the board with suitable documentation, which was hard to do since many Spanish and Mexican titles were vaguely worded, or not worded at all, having been passed down orally from generation to generation. The Board-after a lengthy deliberation often lasting years, during which time Mexican owners were still required to pay taxes on their land and on land improvements made by squatters illegally occupying their land-would then pass judgment on the title and the claimant could choose to pursue the claim further. Many Mexican Californian families, including the Vallejos, lost their lands to the Board and their fortunes to lawyers who often charged outrageous fees to help the Mexicans navigate the US's complicated laws. Bancroft concludes in History of California that "seven-eighths of all the claimants before the commission were virtually robbed by the government. ... As a rule, they lost nearly all their possessions in the struggle before successive tribunals. ... The lawyers took immense fees in land and cattle, often for slight services or none at all.... The estates passed for the most part into the hands of speculators who were shrewd enough and rich enough to keep them" (VI. 576). Mexicans in Arizona, New Mexico, and Texas were subjected to similar treatment. Their families having lost their fortunes, the sons and daughters of the once wealthy, powerful, and respected Californios were left to shift for themselves and so entered the labor force in increasingly proletarian and menial jobs. The effects of the Land Commission are described in excruciating detail in María Amparo Ruiz de Burton's 1885 novel The Squatter and the Don, the main character of which-Don Mariano-was based on Vallejo. A thorough account of the Land Commission can be found in volume VI of Bancroft's History of California, Leonard Pitt's The Decline of the Californios (1966), and Tómas Almaguer's Racial Fault Lines: The Historical Origins of White Supremacy in California (1994).

3. For a detailed discussion of these changes see Almaguer, Chapter 1, "We Desire Only a White Population in California': The Transformation of Mexican California in Historical-Sociological Perspective," and Pitt, specifically Chapter 14, "Upheavals-Political and Natural, 1860-1864." For a consideration of California and the West in the broader context of US history see Robert Cook's Civil War America: Making a Nation 1848-1877 (2004), especially Chapter 8, "The Land of Gold: The Far West in the Mid-Nineteenth Century."

4. Theorizations of race and nation with a US focus have emphasized the symbiotic relationship between economic institutions and ideological concepts such as freedom and citizenship, which has, in turn, informed notions of race since the country's founding. Omi and Winant's groundbreaking 1986 study Racial Formation in the United States: From the 1960s to the 1990s argues powerfully that race and racism are historical constructs that change over time. They are not only fundamental external structures that shape our identities, but also integral parts of US institutions. Building on their work, in Racial Faultlines Almaguer shows how post-1848 westward migration "forged a new pattern of racialized relationships between conquerors, conquered, and the numerous immigrants that settled in the newly acquired territory" (1). Combining the theoretical revelations of both these studies, Evelyn Nakano Glenn's Unequal Freedom: How Race and Gender Shaped American Citizenship and Labor (2002) demonstrates how citizenship is the necessary outgrowth of the tension between universalism and exclusion contained within philosophies of race, gender, and labor; topoi that Nakano Glenn argues cannot be considered in isolation. 
5. Vallejo demonstrates a cosmopolitan awareness lacking in most other testimonios. In this sense, his text has less in common with testimonios of the oppressed and can be more rightly considered in conjunction with other nineteenth-century Latin American narratives such as Chilean adventurer Vicente Pérez Rosales's Times Gone By: Memoirs of a Man of Action (2003), or Domingo Sarmiento's Facundo (1845), both of which place their countries' histories-Chile and Argentina, respectively-in an international context and use revolution as occasion for meditation on the meaning of the Americas.

6. The Historical Works pamphlet goes on to describe this division of labor, as do Bancroft in Literary Industries: A Memoir (1891), Henry L. Oak in "Literary Industries" in a New Light (1893), Sánchez in Telling Identities, and countless articles in contemporary journals of Bancroft's day.

7. "It's very possible that Mr. Bancroft finds 'that the dates which you have sent him are at variance with much that others have written,' but what to do, my friend? Everything I have told you I am prepared to prove with reliable documents and signatures that corroborate my assertions. The history of Alta California is being dealt with and it is necessary to be true and impartial. I am reminded of the words of Cicero who said: "history is the witness of the times, the light of truth, the messenger of antiquity." (Unless otherwise noted, all translations are my own; all misspellings appear in the original.)

8. Henry Oak, Bancroft's head librarian, describes the various controversies that plagued Bancroft and his Works in his memoir "Literary Industries," $12-18$.

9. In his biography Hubert Howe Bancroft: Historian of the West (1946), James Caughey gives a full account of these claims (266-70). Caughey tells of how Frances Fuller Victor took out notices in Oregon and Utah papers asserting that she was responsible for Bancroft's volumes on the region. At the San Francisco Winter Fair of 1893 Victor displayed four volumes of the work with her name inserted on the title page as author. Similarly, Henry Oak donated ten volumes of the Works with his name inserted in the preface to the library at Dartmouth, his alma mater. Oak's memoir, "Literary Industries," deals with these claims at length (33-55).

10. The Society of California Pioneers launched one of the most vocal, public, and aggressive campaigns against Bancroft, ultimately revoking his honorary membership in the Society. In their proceedings for November 1893, the Society writes, "Bancroft, in his so-called 'History of California' has, within the personal knowledge and recollection of many of the old pioneers here present, distorted the facts and truths of such history, and maligned the memory of many of the men most conspicuous as participants in these early events" (6). At issue is Bancroft's portrayal of John Frémont as "a 'filibuster,' whose almost every act in California was a wrong from beginning to end" (7). The Society claims that Bancroft's portrait of Frémont is without documentary support and is simply evidence of Bancroft's "apologetic efforts to present the case in the strongest possible pro-Mexican and anti-American spirit" (15).

11. Bancroft's assumption of writerly objectivity is rooted in the notions of historical objectivism that, as Novick describes, emerged at the end of the 
nineteenth century. The possibility of objectivity and the notion of an abstract intellect underlie the development of Western modernity, of which I argue Bancroft is an example. Western modernity, in turn, relies on the imperial invention of race, as Anne McClintock argues in Imperial Leather: Race, Gender, and Sexuality in the Colonial Context (1995). McClintock describes how the "invention of race in the urban metropoles ... became central not only to the selfdefinition of the middle class but also to the policing of the 'dangerous classes': the working class, the Irish, Jews, prostitutes, feminists, gays and lesbians, criminals, the militant crowd and so on" (5). In other words, the corporeal, racialized masses form the core of a modern, Anglo identity, a process we see in action in Bancroft's bodily othering of Vallejo.

12. "[s]ince he says that history must be written slowly and not like a Yankee on horseback."

13. "I have not had, nor do I have the intention or desire to deviate from the truth."

14. "I propose nothing less than to bequeath to posterity a true history of the facts, just as they have taken place, in which each actor, each town, and each city will appear according to his or its just merits" (Hewitt translation; all citations from the Recuerdos will read as follows: Volume. manuscript page/translation page).

15. "[c]ompendium of the true history of California" (Hewitt translation).

16. See letter to Cerruti, 21 April 1874.

17. "[t]hat history should be just as Cicero painted it, "the light of truth, as well as time's witness."”

18. "[i]s a true reflection of the facts, manner of thinking, and customs which ruled amongst us in 1815."

19. " $[\mathrm{I}] \mathrm{t}$ was reserved to the Americans to change the name of this place and to call the 'Punta de Quintín' 'Point San Quentin.' Whatever may have been the North American's motive in effecting such a change I do not know, but I think it can be attributed to the fact that a great number of them came to California in the belief that the inhabitants of this country were mostly Catholics; with the aim of ingratiating themselves to them they added 'San' to the names of the towns and villages they visited. I recall upon different occasions having heard mention of Santa Sonoma, San Monterey, and San Branciforte and guided by this custom they added San to Quintín's name; about this behavior I have no comment except to admit the Latin saying 'there's no arguing with taste.' If 'San Quentin' pleases them more than the simple 'Quintín' then let them have their vision and their saint, I'm sure I don't envy them."

20. "I still recall the toast by señor Echeandía and I think it opportune to reproduce it, for, although forty-three years have passed since then I still recall it with pleasure" (Hewitt translation).

21. "The décimas are terrible. They have no literary merit whatever, but they secured political and domestic peace for Buelna. This proves how well-grounded 
was the ancient Latin proverb- 'A tiny spark overlooked has often started a great conflagration"” (Hewitt translation).

22. " $[\mathrm{h}]$ as been the cause of three-fourths of the revolutions that have destroyed Mexico, and moreover the republics of Central and South America, in the past fifty years."

23. "While he was captive, he relegated his glorious antecedents to oblivion, recognized the independence of Texas, and, to the great disgrace of the Mexican Republic, it was humbled to the government of the United States which, despite existing treaties with a sister republic, had incited the rebellion of a group of its citizens against the president of the Republic."

24. "[W]ill be able to judge as to the manner in which this document has influenced the well-being of the Mexican Republic which during the passage of the last forty-seven years has so many times been the plaything of the ambitious aims of certain of her renegade sons whom, deaf to the wail of anguish ... ceaselessly and pitilessly slashed at the vitals of that motherland which owes to them all her grief and lassitude."

25. "[a]re studiously kept in barbarism and ignorance."

26. "[a]ll the fervor of [his] Republican soul ... boasting publicly of his wantonness and disregard for the good opinion of virtuous people." Governor Chico, according to Vallejo, had left his wife in Mexico and was living with a "mujer libertina" (a libertine) whom Vallejo admits is very beautiful. Although he feels sympathy for those "que sucumben á los ataques de Venus" (succumb to Venusian attacks), Vallejo feels such behavior is unacceptable in a public official.

27. "[b]ore the stamp of absurdity rather than patriotism."

28. "This should cause no wonder, however, for it is well known that the presidents of the Mexican Republic only remembered about California when someone visited them personally or we through our deputy caused some letter or present to reach their hands."

29. "[f]or the most part people devoid of any attributes that might ennoble a mandatary."

30. "California is free and will sever all her relations with Mexico until the latter ceases to be under the heel of the present dominant faction called the 'Central Government'” (Hewitt translation).

31. "[a]s an impartial writer it is incumbent upon me to draw aside the veil concealing the motives which caused the erudite but ill-intentioned poet to vilify the successful opponents of Guttiérrez" (Hewitt translation).

32. "Californio born in this beautiful land that used to belong to the Mexican Republic."

33. "The arrival of so many guests filled us northerners with happiness, for we saw with great pleasure that many groups of industrious people had come from the other side of the Sierra Nevadas to set up camp amongst us." 
34. "How beautiful it would have been had the exaggerated enlightenment which the Americans have brought to California not perverted our patriarchal customs and relaxed the morality of our young people."

35. "[a] showy people with a tendency for windy sentiments and [for whom] it is very difficult when in a foreign country to forget the customs of their own country which are so different from the majority of other peoples'."

36. "[i]nstrumentalities of foreign politics" (Hewitt translation).

37. "European civilization was coming upon [them] with giant strides" (Hewitt translation).

38. "[d]uring the brief passage of time that Alta California remained separated from the government of the mother country which had so oppressed us ... the citizens of the universe were cheerfully invited to prosper in a broad field under the shelter of wise and prudent laws."

39. "[t]hose of us who feel these ills most immediately should undertake to create their remedy, if we be moved by a lively desire for national prosperity, while simultaneously bearing our own private interests in mind."

40. "The happiness of nations is not made by many leagues of land, rather it is made by the people and by order ... wise laws are more useful to the states than subjection and ... development is the soul of stability and not coercive management."

41. "[b]een carried into effect [it] would have given the port of Monterey great maritime importance" (Hewitt translation).

\section{Works Cited}

Almaguer, Tómas. Racial Fault Lines:

The Historical Origins of White

Supremacy in California. Berkeley: U

of California P, 1994.

Bancroft, Hubert Howe. History of

California. Vol. I-VII. San Francisco:

Bancroft, 1884-90.

\section{Literary Industries:}

A Memoir. San Francisco: History Co., 1891.

Letter to Platon Vallejo. 12

Nov. 1915. Hubert Howe Bancroft

Papers: Additions. BANC MSS 73/37

c. Bancroft Library, U of California,

Berkeley.
Bruce-Novoa, Juan. Retrospace:

Collected Essays on Chicano

Literature. Houston: Arte Publico, 1990.

Cerruti, Enrique. Letter to

H. H. Bancroft. 3 March 1874.

Hubert Howe Bancroft: Records of the

Library and Publishing Companies

1864-1910. BANC MSS B - C

7. Bancroft Library, U of California,

Berkeley.

Cerruti, Henry. Ramblings in

California: The Adventures of Henry

Cerruti. Ed. Margaret Mollins

and Virginia E. Thickens. Berkeley:

Friends of the Bancroft Library, 1954. 
Gruesz, Kirsten Silva. Ambassadors of Culture: The Transamerican Origins of Latino Writing. Princeton: Princeton UP, 2002.

The Historical Works of Hubert Howe Bancroft in their Relation to the Progress and Destiny of the Pacific States. San Francisco, 1886.

McClintock, Anne. Imperial Leather: Race, Gender, and Sexuality in the Colonial Context. New York:

Routledge, 1995.

Novick, Peter. That Noble Dream: The "Objectivity Question" and the American Historical Profession. Cambridge: Cambridge UP, 1988.

Oak, Henry L. "Literary Industries" in a New Light: A Statement of the Authorship of Bancroft's Native Races and History of the Pacific States, with Comments on Those Works and the System by Which They Were Written; and the Labors of Assistants. The Whole Being a Reply to Statements and Claims in the Literary Industries. San Francisco: Bacon, 1893.

Padilla, Genaro. My History, Not Yours: The Formation of Mexican American Autobiography. Madison: U of Wisconsin P, 1993.

Rosenus, Alan. General Vallejo and the Advent of the Americans.

Berkeley: Heyday, 1995.
Sánchez, Rosaura. Telling Identities:

The Californio Testimonios. Berkeley:

U of California P, 1995.

Society of California Pioneers.

Misrepresentations of Early California History Corrected: Proceedings of the Society of California Pioneers in Regard to Certain Misrepresentations of Men and Events in Early California History Made in the Works of Hubert Howe Bancroft and Commonly Known as Bancroft's Histories. San Francisco: Sterett, 1894.

Vallejo, Mariano Guadalupe. Historical and Personal Memoirs Relating to Alta California. Vol. I-V. Trans. Earl Hewitt. TS. BANC MSS CD 17-21. Bancroft Library, U of California, Berkeley. Letter to Enrique Cerruti. 21 April 1875. Hubert Howe Bancroft: Records of the Library and Publishing Companies 1864-1910. BANC MSS B-C 7. Bancroft Library, U of California, Berkeley.

- Recuerdos Historicos y

Personales Tocante á la Alta

California, Escritos por Mariano

G. Vallejo, Commandante General que fué de la Alta California desde el año de 1836 hasta el de 1842, Historia Política del País, 1769-1849, Costumbres de Los Californios, Apuntes biográficos de Personas Notables, Tomos $I-V$. BANC MSS CD 17-21. Bancroft Library, $U$ of California, Berkeley. 